\title{
Refleksi Sosial Penyelenggaraan Jenazah bagi Mahasiswa Pendidikan Guru Madrasah Ibtidaiyah
}

\author{
Yasnel \\ Program Studi Pendidikan Guru Madrasah Ibtidaiyah, Universitas Islam Negeri \\ Sultan Syarif Kasim Riau \\ e-mail: yasnel.yasnel@uin-suska.ac.id
}

\begin{abstract}
Every living being will die eventually, which the time of its coming is unknown for being a divine secret. Therefore, every buman being is required to always prepare for it. If a buman is dead, then the body is called a janazah (corpse). Among the preparations is that humans must be able to perform the bathing and enshrouding of the deceased. However, recent fact shows that many people, including students of Madrasah Ibtidaiyah Teachers Training Program (PGMI) of UIN Suska Riau, are found to be unable to bathe and enshroud the body, because they are scared of the corpse, it can be banded over to others, and other issues which causes them to be incapable of bathing and enshrouding the deceased. This condition is like a disease that plague not only in urban society but also in the countryside. Though Islam recommends that in its implementation, it is more appropriate if the funeral process is carried out by members of the deceased's family. Formulation of problem used is: how is the social reflection of Islamic funeral performance among studens' of PGMI UIN SUSKA Riau. Considering this research is a descriptive qualitative, so the data collection methods used are interview, pre-test and post-test, and documentation. These methods aimed to find out students' ability to bathe and to enshroud janazab before and after the activity, the affecting causes, and other important matters to achieve the expected aim. By performing the Islamic Funeral demonstration for students of PGMI UIN SUSKA Riau, it is expected that the students are able to bathe and to enshroud janazah as well as to reflect the learning to their social life wherever they are.
\end{abstract}

Keywords: funeral, corpse/janazah, bathing, enshrouding

\section{PENDAHULUAN}

"Tiap-tiap yang bernyawa akan merasakan mati. Kemudian hanya kepada Kami kamu dikembalikan"(Q.S. Al-Ankabut: 57) (Yayasan penyelenggara/ Penafsir AlQuran: 2012). Dengan adanya ayat tersebut menunjukkan bahwa Allah Swt melalui Rasul-Nya telah mengajarkan syariat Islam kepada umat manusia di antaranya akan perlu untuk menyadari di kehidupan dimana setiap yang bernyawa pasti akan mengalami yang namanya kematian, dengan tidak akan pernah diketahui kapan waktunya datang. Kondisi itu tentunya memberikan isyarat kepada umat manusia untuk senantiasa mempersiapkan diri menghadapi kematian sepanjang waktu, bagaimanapun adanya.

Manusia sebagai makhluk Allah, diciptakan-Nya sebagai ciptaan yang paling baik dan paling mulia (Yusuf Qardhawi: 2013) dibanding makhluk lainnya (Q.S. Al- 
Tin: 4), (Yusuf Qardhawi: 2013) dengan diberikannya nafsu dan akal. Sebagai makhluk yang paling baik dan paling mulia, Allah telah membuat suatu ketetapan melalui ketetapan syariat Islam dengan menempatkan manusia pada derajat yang paling mulia juga.Sebagai wujud dari kemuliaan yang diberikan Allah kepada manusia, Allah telah menetapkan aturan khusus dalam syariat Islam dengan diperintahkannya kepada manusia yang masih hidup untuk melaksanakan beberapa kewajiban terhadap orang yang meninggal/ jenazah sebagai salah satu bentuk Allah sangat menghormatinya.Di antara kewajiban-kewajiban yang perlu dilakukan terhadap jenazah dalam Islam adalah memandikan, mengafani, menshalatkan, menguburkan dan lain sebagainya.

Dalam Islam melakukan beberapa penyelenggaraan yang telah ditetapkan terhadap jenazah yang muslim hukumnya adalah fardhu kifayah (Sulaiman Rasjid: 1994) dalam artian suatu kewajiban seluruh umat Islam ketika diselesaikan oleh satu orang saja terbayarkan kewajiban umat Islam lainnya. Walaupun kewajiban terkait penyelenggaraan jenazah bisa terbayarkan oleh satu orang saja, Islam memberikan isyarat agar umat Islam harus mampu melakukan penyelenggaraan jenazah sesuai dengan tuntunan yang telah disampaikan melalui ajaran yang telah disampaikan Rasul kepada umatnya. (Ma'mur Daud: 1982)Dalam Islam yang lebih afdhal pada penyelenggaraan memandikan dan mengafani jenazah adalah keluarga terdekatnya, karena dikhawatirkan adanya aib di tubuh jenazah (Sulaiman Rasjid: 1994).

Jika penyelenggaraannya dilakukan oleh keluarga terdekatnya, adanya aib di tubuh jenazah kemungkinan besarnya tidak akan diceritakan pada orang lain. Walaupun demikian, dalam syariat Islam juga diperbolehkannya orang lain atau orang yang bukan dari anggota keluarga jenazah pada penyelenggaraannya termasuk pada hal memandikan dan mengafani jenazah. Terkait itu Hadis Nabi telah memberikan isyarat dengan mengatakan: "Dari Aisyah, Rasulullab bersabda: "Barang siapa yang memandikan mayat dan dijaganya kepercayaan, tidak dibukakannya kepada orang lain apa-apa yang dilibat pada mayat itu, maka bersiblah ia dari segala dosanya, seperti keadaannya sewaktu dilabirkan oleh ibunya". Kata Beliau lagi: "Yang mengepalainya bendaklah keluarga terdekat kepada mayat jika ia pandai memandikan mayat. Jika ia tidak pandai, maka siapa saja yang dipandang berbak karena wara'nya atau karena amanabnya." (H.R. Ahmad)(Sulaiman Rasjid: 1994). Tentunya, jika yang meninggal dua orang tua (ibu dan bapak), melakukan penyelenggaraan jenazahnya akan lebih afdhal dilakukan oleh anaknya sebagai bagian dari birrul walidain. Semenjak kedatangan Islam di muka bumi yang dibawa Nabi Muhammad Saw telah memberikan perhatian yang amat besar bagi pemecahan masalah social yang dihadapi umat (Abuddin Nata: 2014).

Memperhatikan fenomena yang terjadi di kalangan masyarakat akhir-akhir ini, banyaknya umat Islam yang mengaku beragama Islam tetapi tidak tahu dengan ajaran agamanya termasuk dalam hal penyelenggaraan jenazah.Fenomena itu bagaikan penyakit yang mewabah di kalangan umat Islam, yang tidak hanya di perkotaan tetapi juga di desa-desa.Ketidaktahuan atau ketidakmampuan umat Islam dalam penyelenggaraan jenazah terutama dalam memandikan dan mengafani jenazah dilatarbelakangi dengan alasan mereka yang bermacam-macam. Di antara yang menjadi alasan mereka tidak tahu dan tidak mampu memandikan jenazah katanya 
(Wawancara yang dilakukan dengan masyarakat Pekanbaru di RT 02/ RW 02 Pekanbaru dan beberapa orang masyarakat desa Balung Kecamatan XIII Koto Kampar) :Pertama, disebabkan karena ketakutan jika mereka yang memandikan atau mengafani jenazah, akan menghantuinya. Kedua, penyelenggaraan jenazah bisa diupahkan kepada orang lain. Karenanya menyebabkan mereka tidak mencaritahu akan pelaksanaannya.

Adanya ketakutan masyarakat untuk memandikan dan mengafani jenazah sebenarnya menggambarkan ketidaksadaran masyarakat bahwa dia atau anggota keluarganya suatu saat juga akan menjadi jenazah. Ketakutan masyarakat sebagaimana telah disampaikan sebelumnya telah berdampak pada tidak banyaknya masyarakat yang tahu dan terampil untuk memandikan dan mengafani jenazah. Jika kondisi masyarakat seperti itu dibiarkan berkelanjutan, tentunya dapat dipastikan bahwa untuk penyelenggaraan jenazahnya atau keluarganya tidak akan dilakukan oleh keluarga terdekatnya tetapi diselenggarakan oleh orang lain satu sisi. Sementara di sisi lain, jika kondisi itu dibiarkan, tentunya akan semakin mengecil orang yang mampu dalam penyelenggaraan jenazah atau tidak adanya suatu saat ditemukan orang yang mampu dalam penyelenggaraan jenazah. Sekarang saja, jumlah masyarakat yang mampu terkait itu tidak banyak jumlahnya di suatu tempat. Mirisnya lagi, ditemukan juga adanya masyarakat yang tidak hanya membayar seseorang pada penyelenggaraan memandikan dan mengafani jenazah, bahkan untuk mendoakan jenazahpun mereka bayar orang lain. Jika kondisi itu terjadi pada orang tua, tentu dapat dikatakan suatu kejadian umat Islam yang sangat memprihatinkan. Orang tua yang semenjak kecil menyayangi, merawat anaknya, menjaga, membiayai, membesarkan, dan lain sebagainya tanpa kenal lelah melakukannya bagaikan matahari yang rela terbit setiap hari dengan ikhlah tanpa mengharapkan balasan, di akhir keberadaannya di dunia, anaknya tidak memberikan apa-apa padanya walau hanya doa.

Berdasarkan studi pendahuluan yang telah dilakukan melalui wawancara dengan beberapa orang mahasiswa yang menjadi lokasi dilaksanakannya pelatihan jenazah terkait memandikan dan mengafani jenazah, diperoleh informasi sebagai berikut:

1. Menggejalanya akhir-akhir ini dengan banyaknya umat Islam termasukmahasiswa sebagai anak atau keluarga terdekat yang tidak mampu melakukan penyelenggarakan jenazah apalagi memandikan dan mengafaninya sehingga jika ada di suatu keluarga yang meninggal dilakukan oleh orang lain termasuk orang tuanya sendiri. Dengan kondisi itu sebenarnya dikhawatirkan aib yang ada di tubuh mayat diketahui orang lainnya, yang terkadang berdampak menjadi fitnah bagi jenazah jika diselenggarakan oleh orang lain.

2. Di kalangan mahasiswa hanya beberapa orang saja yang dapat dikatakan sebagai orang yang mampu dalam memandikan dan mengafani jenazah.

3. Ketidakmampuan mahasiswa atau umat Islam secara umum untuk memandikan dan mengafani jenazahi antaranya disebabkan juga oleh kurangnya motivasi mereka untuk mampu memandikan dan mengafani jenazah karena ketakutan mereka dihantui oleh mayat yang mereka mandikan, dan lain-lain. 
4. Adanya seseorang yang meninggal dunia menjadi rahasia Ilahi, kapan dan di mana saja Allah kehendaki.

Dengan adanya permasalahan di atas, apalagi adanya kemungkinan orang meninggal di suatu waktu yang menjadi rahasia Ilahi, diperlukan adanya mahasiswa harus mampu dalam memandikan dan mengafani jenazah apalagi adanya anjuran dalam Islam akanlebih afdhalnya keluarga terdekat dalam penyelenggaraan jenazah. Oleh karena itu, kiranya dirasa untuk melaksanakan pelatihan penyelenggaraan memandikan dan mengafani jenazah bagi Mahasiswa Pendidikan Guru Madrasah Ibtidaiyah UIN Suska Riau, dengan judul: Refleksi Sosial Pelatihan Penyelenggaraan Jenazah Bagi Mahasiswa Pendidikan Guru Madrasah Ibtidaiyah UiINSuska Riau (Alaiddin Koto: 2010).Dengan adanya pelatihan memandikan dan mengafani jenazah diharapkan dapat memberikan pengetahuan kepada mahasiswa tentang tata cara memandikan dan mengafani jenazah sehingga mereka mampu menyelenggarakannya. Selain itu, dengan adanya pelatihan dapat menumbuhkan kesadaran mahasiswa untuk ikut ambil bagian dalam penyelenggaraan jenazah termasuk memandikan dan mengafani jenazah sebagai refleksi sosialnya terhadap lingkungannya.

UIN Suska Riau sebagai salah satu lembaga pendidikan yang berperan mencerdaskan anak bangsa, dengan adasalah satu program pendidikan yang dilaksanakannya pelatihan penyelenggaraan jenazah tentunya dapat memberikan keterampilan bagi mahasiswa sebagai bagian dari manfaatnya sekaligus perwujudan Tri Dharma Perguruan Tinggi. Dengan adanya pelatihan penyelenggaraan jenazah bagi mahasiswa, sebenarnya itu adalah sebagai bentuk refleksi social atau kepedulian sosial UIN Suska Riau terhadap permasalahan yang dihadapi masyarakat termasuk kepedulian terhadap permasalahan dosennya yang harus melakukan Tri Dharma Perguruan Tingganya sekaligus membantu program pemerintah, selain sebagai bentuk aktualisasi ajaran Islam.

\section{METODOLOGI}

Pelatihan penyelenggaraan jenazah dilaksanakan di Jurusan PGMI Fakultas Tarbiyah dan Keguruan UIN Suska Riau dengan pesertanya adalah mahasiswa PGMI. Metode yang digunakan dalam pelaksanaannya adalah melalui metode observasi, wawancara, tes sebelum dan setelah pelaksanaan pelatihandan dokumentasi.Metode tersebut ditujukan untuk mengetahui kemampuan mahasiswa sebelum dan setelahnya sehingga diharapkan terefleksi dalam kehidupan sosialnya. Dan pada akhirnya setelah kegiatan pelatihan dilaksanakan, dilakukan evaluasi kegiatan (Muhaimin: 2001). 


\section{TEMUAN DAN DISKUSI}

\section{A. Pertolongan Pertama atau Upaya yang Dilakukan Terhadap Orang yang Baru Meninggal}

Jika pada suatu hari seorang muslim menyaksikan adanya saudara sesama muslim yang baru meninggal, maka sebaiknya sikap sikap secepatnya yang harus dilakukan terhadap orang yang baru saja meninggal adalah:

1. Merapatkan atau memejamkan matanya: (Ibn Rusyd: 1996). Sebaiknya jika seseorang merapatkan mata mayat ia membaca doa sebagai berikut:

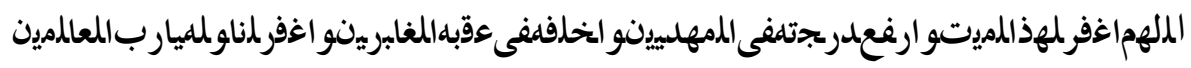

2. Merapatkan mulut mayat. Jika terbukanya dengan kondisi sulit untuk dirapatkan, satu pendapat katakan dengan mengikat dagu ke atas kepalanya jika itu yang terbaik.

3. Menutup badan jenazah dengan kain agar auratnya tidak terlihat, atau disebut juga menyelimuti mayat.

4. Memberitahu keluarga, kerabat, dan handai taulan lainnya.

5. Tidak adanya larangan untuk mencium mayat bagi keluarga atau kerabat yang sangat sayang dan berduka cita karena kematiannya.

6. Membayar hutang mayat, jika mampu, dibayar dari hartanya atau dari harta keluarganya. Hadis Nabi katakan: Dari Abi Hurairah, Rasulullah Saw telah bersabda: "Diri orang mukmin itu tergantung (tidak sampai ke hadirat Ilahi) karena butangnya, bingga dibayar dabulu butangnya itu (oleh familinya)." (H.R. Ahmad dan Tirmizi) (Sulaiman Rasjid: 1994).

7. Tidak melukai sebagaimana tidak melukai orang yang masih hidup.

8. Tidak mencelanya, dan lain-lain.

\section{B. Tata Cara Memandikan dan Mengafani Jenazah}

Ada beberapa pendapat yang berkembang di kalangan masyarakat tentang syarat atau ketentuan terhadap jenazah yang dimandikan yang perlu diketahui sebelum memandikan jenazah.

1. Syarat atau ketentuan terhadap jenazah yang dimandikan yaitu:

a. Jenazah atau mayat adalah orang Islam, tidak orang kafir.

b. Didapati tubuhnya walau hanya sabagiannya saja. Secara umum para imam mazhab berbeda pendapat, di antaranya, Imam Hambali dan Imam Syafii' berpendapat: tetap dimandikan walau hanya didapat sebagian tubuhnya saja. Dan terkait itu Imamiyah berpendapat wajib dimandikan dan kewajiban lainnya termasuk menshalatkannya. Jika hanya yang ditemukan sepotong tulangnya saja, kewajiban terhadapnya adalah memandikan, membungkusnya dengan sehelai kain kafan, yang kemudian menguburkannya (Muhammad Jawad Mughniyah: 2010).

c. Jenazah tidak mati syahid, dengan dasar hukumnya Hadis Rasulullah Saw:




Artinya: "Sesungguhnya Nabi Muhammad Saw tidak memandikan dan tidak menshalatkan orang yang mati syahid di medan perang uhud." (H.R. Imam Bukhari) (Muhammad Jawad Mughniyah: 2010).

2. Syarat atau ketentuan terhadap orang yang berhak memandikan jenazah dalam Islam adalah:

a. Jenazah laki-laki dimandikan oleh laki-laki, sementara jenazah yang perempuan dimandikan oleh perempuan pula dengan maksud suapaya tidak menimbulkan syahwat. Sementara berdasarkan pendapat jumhur ulama, orang yang berlainan jenis yang boleh memandikan jenazah adalah muhrim, suami atau isteri Ibn Rusyd : 1996).

b. Yang lebih utama memandikannya adalah keluarga terdekatnya mayat.

c. Orang yang memandikan jenazah apabila mendapati cacat atau adanya aib di tubuh jenazah, tidak menceritakannya kepada orang, yang disebut juga sebagai orang yang dapat berlaku amanah. Berlaku amanah diartikan juga dengan:

1) Kemampuannya dalam memandikan mayat tidak diragukan orang.

2) Apabila ia memberikan suatu kegembiraan yang tampak dari jenazah, maka beritanya dapat dipercaya. Selanjutnya jika ia melihat hal-hal buruk dari diri jenazah, ia mampu merahasiakannya. Nabi Muhammad Saw bersabda: "Sebutkanlah kebaikan-kebaikan orang yang mati di antaramu dan jagalah kejelekan-kejelekannya." (H.R. Abu Daud dan Tirmizi).

d. Apabila tidak mendapatkan adanya orang yang sejenis dengan mayat, atau tidak adanya muhrim, atau suami atau isteri mayat, maka mayat tersebut menurut pendapat ini ditayamumkan saja (Ibn Rusyd: 1996).

3. Urutan orang-orang yang lebih utama untuk memandikan jenazah yang laki-laki adalah ahli waris ashabah laki-laki, kerabat laki-laki yang lain, isteri, dan orang laki-laki yang lain. Yang dimaksud denganahli waris ashabah adalah:

a. Ayah.

b. Kakek dan ke atasnya seperti ayahnya kakek dan seterusnya.

c. Anak laki-laki.

e. Cucu laki-laki dan ke bawahnya.

f. Saudara laki-laki kandung.

g. Saudara laki-laki seayah.

h. Anak dari saudara laki-laki kandung.

i. Anak dari saudara laki-laki seayah, dan seterusnya (Sulaiman Rasjid: 1994). Menurut Ibn Rusyd, muhrim laki-laki tidak boleh memandikan jenazah murimnya yang perempuan (Ibn Rusyd: 1996). Jika yang meninggal adalah laki-laki sementara laki-laki tidak ada dan muhrimnya juga tidak ada, maka sebaiknya mayat ditayamumnya saja dengan menutup anggota tubuhnya yang lain (Sulaiman Rasjid: 1994 dan Ibn Rusyd: 1996).Dan para ulama sepakat terhadap suami atau isteri yang sudah mentalak secara ba'in tidak boleh memandikan isteri atau suaminya.Sementara memandikan isteri atau suami dalam kondisi talak raj'i para ulama berbeda pendapat menjelaskan hukum memandikannya, ada yang menyatakan boleh dan ada juga yang mengatakan tidak boleh karena dipandang tidak muhrim lagi (Ibn Rusyd: 
1996).Dan Abu Hanifah berpendapat bahwa suami tidak boleh memandikan jenazah isterinya (Ibn Rusyd: 1996).

4. Mempersiapkan hal-hal yang dibutuhkan ketika memandikan jenazah:

a. Menyediakan air yang bersih lagi membersihkan.

b. Menyiapkan sabun untuk membersihkan jenazah. Jika sabunnya sabun batangan dengan dihancurkan terlebih dahulu sebelum mayat dimandikan atau daun bidara atau sesuatu yang menghilangkan daki (Sulaiman Rasjid: 1994).

c. Menyiapkan sampo atau daun kelor dan sisir untuk rambut jenazah jika diperlukan.

d. Menyiapkan kapur barus yang telah dihancunkan dengan disaring terlebih dahulu setelah proses menghancurkannya (Ibn Rusyd: 1996), dan lain-lain. Dan para Imam mazhab yang empat tidak mewajibkan menggunakan daun bidara atau kapur barus tetapi dikatakan hukumnya sunat (Muhammad Jawad Mughniyah: 2010). Jika tidak memungkinkan jenazah untuk dimandikan karena adanya uzur yang disebabkan tidak adanya air, terbakar, sakit yang sekiranya jika dimandikan, daging atau kulit mayat akan rusak, maka menurut kesepakatan semua ulama imam mazhab, jenazahnya boleh ditayamumkan sebagai pengganti mandinya. Dan untuk cara-cara bertayamumnya sama dengan cara tayamumnya orang yang masih hidup (Muhammad Jawad Mughniyah: 2010).

e. Menyiapkan kain kafan sebanyak keperluan, dan lain-lain.

5. Tempat memandikan jenazah

Sebaiknya pada prosesi memandikan jenazah dilaksanakan pada tempat yang memenuhi kriteria sebagai berikut:

a. Sepi atau di tempat yang tertutup, yang diperkirakan tidak dilihat orang kecuali petugas yang memandikannya atau petugas yang telah dipercayai membantunya.

b. Ditaburi wewangian untuk mencegah bau yang keluar dari tubuh jenazah.

5. Etika memandikan jenazah

Ada beberapa etika yang perlu diketahui oleh umat Islam terkait memandikan jenazah:

a. Tidak melihat aurat jenazah kecuali untuk kesempunaan memandikannya seperti untuk memastikan air yang disiramkan sudah merata, atau untuk menghilangkan kotoran yang bisa mencegah sampainya air pada kulit.

b. Menggunakan alas atau sarung tangan saat menyentuh aurat jenazah.

c. Jenazah dibaringkan atau diletakkan di tempat yang lebih tinggi, seperti di atas dipan, atau dipangku oleh 3 atau 4 orang dengan posisi kepala jenazah lebih ditinggikan dari tubuhnya untuk mencegah dari percikan air yang lebih baik.

d. Memandikan jenazah dengan kondisi tertutup semua anggota tubuhnya. Jika tidak memungkinkan karena adanya kesulitan, maka cukup dengan menutup auratnya saja.Dalam Islam memandikan jenazah adalah diperintahakan, sedangkan laki-laki melihat ayrat perempuan atau perempuan melihat aurat laki-laki adalah dilarang (Ibn Rusyd: 1996). 
e. Dianjurkan menggunakan air dingin yang tawar karena lebih bisa menguatkan daya tahan tubuh jenazah, kecuali bila cuaca dingin. Jika cuaca dingin, memandikan jenazah sebaiknya dengan menggunakan air yang hangat.

f. Pakaian jenazah sebaiknya diganti dengan kain sarung sebagai kain basahan untuk mandinya supaya auratnya tidak mudah terlihat (Sulaiman Rasjid: 1994).

g. Dan yang lainnya dipandang perlu seperti air yang disiapkan diletakkan di tempat yang lebih besar.

6. Urutan pada pelaksanaan memandikan jenazah

Dengan diketahuinya beberapa aturan pada penyelenggaraan memandikan jenazah sebagaimana telah dijelaskan sebelumnya, selanjutnya melakukan penyelenggaraan memandikan jenazah. Al-Hasan dan Sa'id bin Musayyab mengatakan, "Setiap muslim yang mati harus dimandikan, karena setiap mayat berhadas besar."( Ibn Rusyd: 1996). Tata cara memandikan jenazah yang berkembang atau yang biasanya dilakukan masyarakat ada beberapa persi pendapat:

a. Dilakukan sebagai berikut: Jenazah pada posisi sedikit didudukkan sementara punggungnya sedikit diangkat atau ditinggikan sambil sedikit menekan perut jenazah supaya kotorannya keluar. Perbuatan itu sebaiknya diringi dengan mengguyurkan air dan wangi-wangian/ air wangi untuk menghilangkan bau kotoran yang keluar.Setelah itu jenazah ditelentangkan kembali, lalu dicebokkan dengan tangan kiri dengan memakai sarung tangan.Setelah selesai dicebokkan, sarung tangan yang digunakan untuk mencebok jenazah diganti dengan sarung tangan yang baru lainnya atau yang bersih.Selanjutnya jari tangan yang kiri dimasukkan ke mulut mayat untuk membersihkan gigi dan mulutnya dengan menggosoknya.Setelah itu membersihkan badan, rambut jenazah dan jenggotnya jika ada dengan air sabun atau daun bidara atau sampo atau daun kelor dengan sedikit menggosoknya hingga diperkirakan bersih, dan setelah itu dibilas.Setelah itu diwudhukkan.Setelah diwudhukkan, dimandi tigakan/ limakan atau sembilankan dimana yang terakhirnya dengan air kapur barus atau wangiwangian supaya jenazahnya lebih harum. Rasulullah Saw bersabda: "Dari Ibn Abbas, ia berkata, "Tatkala seorang laki-laki jatuh dari kendaraannya lalu dia meninggal, sabda Rasul, "Mandikanlah dia dengan air serta daun bidara (atau dengan sesuatu yang menghilangkan daki seperti sabun". (H.R. Bukhari dan Muslim)(Ibn Rusyd: 1996).

b. Proses memandikan jenazah bentuk lainnya dilakukan dengan cara: Mengguyurkan air biasa ke tubuh jenazah dengan gayung di atas tangan kiri dengan posisi tidak terlalu tinggi. Setelah itu membersikankan badan, rambut jenazah dan jenggotnya jika ada dengan air sabun yang telah dihancurkan atau dengan sampo dengan sedikit menggosoknya sampai diperkirakan bersih.Selanjutnya memposisikan jenazah dengan posisi sedikit didudukkan sementara punggungnya sedikit diangkat atau ditinggikan sambil sedikit menekan perut jenazah supaya kotorannya keluar.Perbuatan 
itu sebaiknya diringi dengan mengguyurkan air dan wangi-wangian/ air wangi untuk menghilangkan bau kotoran yang keluar.Setelah itu jenazah ditelentangkan kembali, lalu dicebokkan dengan tangan kiri dengan memakai sarung tangan.Setelah selesai dicebokkan baik bagian kubul dan duburnya, sarung tangan yang digunakan untuk mencebok jenazah diganti dengan sarung tangan yang baru lainnya atau yang bersih.Selanjutnya jari tangan yang kiri dimasukkan ke mulut mayat untuk membersihkan gigi dan mulutnya dengan menggosoknya termasuk membersihkan tempat yang terselip lainnya dari jenazah seperti ketiaknya jika memungkinkan, dan lainlain.Selanjutnya mensugikan jenazah dengan membersikan hidung, mulut (mengkumur-kumurkan jenazah tidak dengan membuka mulut jenazah yang dikhawatirkan masuknya air ke dalam perut jenazah) dan jari-jari mayat jenazah.Setelah itu jenazah diguyur dengan air bersih. Setelah jenazah mandi bersih, jenazah diwudhukkan seperti layaknya wudhuk orang yang masih hidup, dengan niat :

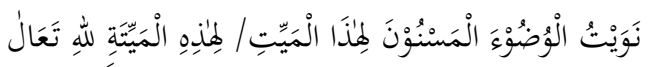

Artinya: Sengaja akumewudu'kan mayat laki-laki/ perempuan ini karena Allah Swt. Mengingat ini adalah kerangka niat, tentunya niat dipasang dalam hati.

Setelah mayat atau jenazah selesai diwudhu'kan, dilanjutkan dengan memandi sembilankan jenazah dimana di antara mandi sembilannya itu terakhirnya dengan air kapur barus. Sebelum memandi sembilankan jenazah sebaiknya orang yang memandikan jenazah memasang niat di dalam hatinya dengan lafaz atau sebagai kerangka niat memandikannya sebagai berikut:

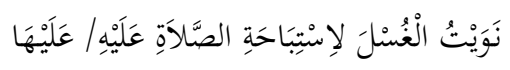

Artinya: Sengaja aku mandi untuk jenazah untuk membolehkan shalat untuknya.

Setelah jenazah dimandi sembilankan, selanjutnya jenazah dikeringkan badan, rambutnya dan jenggotnya jika ada pada tempat yang telah disiapkan sebelumnya.Boleh juga menyisir rambut dan jenggotnya secara perlahan.Jika ada di antara rambutnya yang terpisah atau gugur dari kepala jenazah, sebaiknya disatukan dengan rambut yang dikepalanya sebelum dikafani (Sulaiman Rasjid: 1994).

Dilakukan penyelenggaraan memandikan jenazah sebagaimana telah dijelaskan berangkat dari adanya pandangan yang menjelaskan batas minimun memandikan jenazah yang dipandang cukup sempurna apabila telah melaksanakan sebagai berikut:

a. Menghilangkan najis yang ada di tubuh jenazah.

b. Menyiramkan air secara merata kepada seluruh anggota tubuh jenaza termasuk bagian farji tsayyib (kemaluan wanita yang sudah tidak perawan yang tampak saat duduk, atau bagian alat kelamin laki-laki yang belum dikhitan. Menghilangkan najis di tubuh jenazah yang sulit dihilangkan, bisa diganti dengan tayamum.Cara mentayamumkan jenazah adalah dengan cara menepukkaan kedua telapak tangan pada debu yang 
digunakan untuk mengusap muka dan kedua tangan jenazah, dimana tangan kiri mengusap tangan kanan jenazah, dan tangan kanan untuk mengusap tangan kiri jenazah, dengan niat yang berkelanjutan sampai tayamum selesai.

7. Batas Maksimum Memandikan Jenazah

Batas maksimum atau dipandang sebagai memandikan jenazah yang sudah sempurna jika telah melaksanakan hal-hal sebagai berikut:

a. Mendudukkan jenazah dalam posisi agak condong ke belakang.

b. Pundak jenazah disanggah tangan kanan dengan meletakkan ibu jari pada tengkuk jenazah, sementara punggungnya disanggah dengan lutut.

c. Perut jenazah sedikit ditekan dengan tangan kiri secara perlahan supaya kotoran yang ada di perutnya bisa keluar (Ibn Rusyd: 1996).

d. Jenazah diletakkan kembali di posisi telentang, yang kemudian dimiring.

e. Membersihkan gigi dan kedua lobang hidung jenazah dengan jari telunjuk tangan kiri yang dialas atau pakai sarung tangan yang basah yang tidak digunakan untuk membersihkan qubul dan dubur.

f. Mewudhu'kan jenazah.

g. Mengguyurkan air ke seluruh anggota tubuh jenazah termasuk jenggotnya jika ada dengan air yang telah dicampur dengan daun kelor atau yang serupa dengan itu.

h. Menyisir rambut dan jenggot jenazah yang tebal secara pelan dengan menggunakan sisir yang longgar giginya agar rambutnya tidak rontok. Bila ada rambut jenazah yang rontok, diambil dan dikuburkan bersama jenazah (Sulaiman Rasjid: 1994).

i. Mengguyur bagian depan tubuh jenazah sebelah kanan mulai dari leher sampai telapak kaki dengan menggunakan air yang dicampur daun kelor atau sabun, yang begitu juga bagian sebelah kirinya.

j. Menggururkan air ke bagian belakang tubuh jenazah sebelah kanan, dengan posisi sedikit dimiringkan mulai dari tengkuk, punggung sampai telapak kaki, yang begitu juga bagian sebelah kirinya.

k. Mengguyurkan air ke seluruh tubuh jenazah dengan menggunakan air yang jernih untuk membersihkan sisa-sisa daun kelor atau sabun atau sampo pada tubuh jenazah.

1. Mengguyurkan air yang telah dicampur sedikir kapur barus ke seluruh tubuh mayat jika jenazah tidak meninggal dalam keadaan ihram. Dan dalam Islam sunat hukumnya bagi yang memandikan jenazah memasang niat memandikan jenazah di dalam hatinya (Muhammad Jawad Mughniyah: 2010).

8. Hukum Mandi bagi Orang yang Memandikan Mayat

Mengenai hukum mandi bagi orang yang telah usai memandikan jenazah para ulama berbeda pendapat menetapkannya.Sebahagian ulama berpendapat bahwa seseorang yang telah selesai memandikan jenazah dikatakannya wajib untuk mandi, sementara sebahagian yang lainnya mengatakan tidak wajib disebabkan berbedanya para ulama dalam memahami hadi Asma terkait.Walaupun demikian, berdasarkan hadis yang diriwayatkan oleh Dawud 
katakan bahwa orang yang memandikan mjenazah sebaiknya mandi dan orang yang mengusungnya sebaiknya berwudhu' (Ibn Rusyd: 1996).

\section{Tata Cara Mengafani Jenazah}

Setelah jenazah selesai dimandikan, kewajiban lainnya yang dilakukan terhadap jenazah adalah mengafaninya. Dalam Islam diatur cara mendapatkan kain kafan untuk jenazah. Sulaiman Rasjid menjelaskan bahwa kain kafan untuk jenazah diambil dari harta jenazah sendiri jika ia meninggalkan harta. Jika ia tidak meninggalkan harta, pengadaan kain kafannya menjadi kewajiban bagi orang atau keluarga yang wajib memberinya belanja ketika ia hidup. Kalau yang wajib memberinya belanja juga tidak mampu mengadakannya, hendaklah diambilkan dari harta baitul mal yang diatur berdasarkan aturan agama Islam. Jika baitul mal tidak ada atau tidak teratur, maka untuk pengadaan kain kafannya menjadi kewajiban umat muslim yang mampu. Demikian juga hal untuk pengadaan keperluan lainnya bagi jenazah (Sulaiman Rasjid: 1994).

Sekurang-kurang kain kafan untuk jenazah dalam Islam adalah selapis, yang menutupi seluruh tubuh jenazah, baik jenazah laki-laki maupun perempuan.Salah satu pendapat para ulama tentang kain kafan menjelaskan bahwa idealnya kain kafan untuk laki-laki 3 lapis kain kafan, dimana setiap lapisnya menutupi seluruh badan jenazah.Sementara sebahagian ulama lainnya menjelaskan bahwa salah satu dari 3 lapis kain kafan itu sebaiknya adalah izar (kain mandi), sedangkan 2 lapis lainnya untuk menutupi seluruh badannya (Sulaiman Rasjid: 1994).Ibn Rusyd menjelaskan bahwa yang diwajibkan dalam mengafani jenazah hanya dengan sehelai kain kafan yang dapat menutupi seluruh tubuh jenazah.Sedangkan menggunakan kain kafan lebih dari satu helai menurut Ibn Rusyd hukumnya sunat.

Sedikit berbeda dengan pendapat yang dikemukakan oleh Ibn Rusyd, Imamiyah menjelaskan bahwa 3 potong kain kafan adalah wajib bukan sunat hukumnya. 3 potong kain kafan tersebut dengan rincian: Pertama, diperuntukkan untuk kain lepas yang dapat menutupi dasar pusar sampai lutut. Kedua, diperuntukkan untuk baju, yang dapat menutupi dua bahunya sampai separuh betisnya.Ketiga, diperuntukkan untuk sarung yang dapat menutupi semua badannya. Dengan begitu dapat dikatakan bahwa para ulama berbeda pendapat dalam menentukan jumlah kain kafan, termasuk juga dalam penggunaannya, tetapi setidaknya kain kafan jenazah harus menutupi seluruh tubuhnya dan juga harus suci (Muhammad Jawad Mughniyah: 2010), tidak berlebihan dalam artian harganya tidak mahal (Muhammad Jawad Mughniyah: 2010) atau jumlah lapis kain kafannya berlebih dari yang diperintahkan dalam agama, karena yang diperbolehkan terkait itu dalam standar umum. Dan kafan untuk jenazah diperintah dalam Islam yang berwarna putih. Rasulullah Saw bersabda:

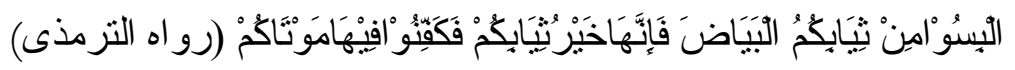

Artinya: Pakailah olehmu kain putihmu, karena sesungguhnya kain putih itu sebaik-baik kainmu, dan kafanilah mayatmu dengan kain putih itu. (H.R. Turmuzi, dan lain-lain)(Sulaiman Rasjid: 1994). 
Selain pendapat di atas, para ulama dalam membicarakan kain kafan untuk jenazah telah membicarakan juga batas minimalnya kain kafan untuk jenazah yaitu satu lembar kain jenazah yang dapat menutup seluruh tubunya. Tidah hanya itu, para ulama juga membicarakan batas kesempurnaan untuk kain kafan jenazah, dengan penjelasannya sebagai berikut:

1. Bagi mayat laki-laki yang lebih utama jumlah kain kafannya adalah 3 lembar/ 3 lapis dengan ukuran panjang dan lebar ketiga kain kafan sama. Selain itu dipandang sempurna juga jika jenazah dikafani dengan 5 lapis kain kafan. 5 lapis kain kafan, bisa terdiri dari 3 lapis dengan ukuran panjang dan lebar ketiga kain kafan sama untuk pembungkus seluruh tubuh, ditambah surban dan baju kurung, atau 2 lapis dengan ukuran panjang dan lebar kedua kain kafan sama untuk pembungkus seluruh tubuh jenazah berdasarkan ukuran panjang jenazah yang dilebihkan satu jengkal dari kepalanya dan satu jengkal dari telapak kakinya, ditambah surban, baju (baju yang dipersiapkan bisa berbentuk jubah dengan ukuran panjangnya dari bahu sampai tumit kaki jenazah dan bisa juga baju biasa dengan ukuran panjangnya dari bahu sampai pinggul jenazah) dan sarung, atau 3 lapis dengan ukuran panjang dan lebar ketiga kain kafan sama, ditambah jubah dan sorban atau yang lainnya selama bilangan lapis kain kafannya ganjil.

2. Bagi jenazah perempuan yang kain kafannya 5 lapis, dapat dialokasikan untuk kain kafan dengan rinciannya 2 lapis kain kafan dengan ukuran panjang dan lebar kedua kain kafan tersebut sama (berdasarkan panjang kain kafan yang diukur dari kepala sampai kaki yang dilebihkan satu jengkal dari kepala dan kaki jenazah) untuk pembungkus seluruh tubuh jenazah, ditambah kerudung, baju kurung (baju yang dipersiapkan bisa berbentuk jubah dengan ukuran panjangnya dari bahu sampai tumit kaki jenazah dan bisa juga baju biasa dengan ukuran panjangnya dari bahu sampai pinggul jenazah) dan sewek/ kain sarung, atau persi yang lainnya sebagaimana yang telah disebutkan sebelumnya.

Untuk memudahkan proses mengafani jenazah, maka urutan peletakannya diletakkan berdasarkan urutan berikut ini:

1. Tali pengikat jenazah. Tali pengikat ini posisinya di atas kepalanya, di atas dadanya, di atas perutnya, di atas lututnya dan di bawah kakinya.Tali ini diambil dari pinggir kain kafan yang dari fabriknya, yang dilakukan pengambilannya setelah kain kafan dipotong atau sebelum dipotong.

2. Kain kafan pembungkus, yang ukuran panjang dan lebarnya sama sebagai telah dijelaskan sebelumnya, dimana di setiap antara lembarannya sampai lembaran terakhirnya ditaburi kapur barus halus yang telah disaring sebelumnya.

3. Baju kurung. Untuk baju kurung, ukurannya dari bahu sampai bawah pinggulnya.Jika bajunya berbentuk jubah, ukurannya dari bau sampai ke tumitnya, jika kainnya memungkinkan.

4. Sarung atau sawek. Sarung atau sawek ukurannya dari pinggang jenazah sampai tumitnya. 
5. Sorban atau kerudung. Untuk panjang sorban atau kerudung dapat diukur dari atas kepala jenazah sampai bawah dadanya.Ke semua alat-alat pengafanan jenazah telah dipersiapkan sebelum jenazah dimandikan.Jika semua perlengkapan pengafanan jenazah selesai disiapkan sementara jenazahnya belum dimandikan, sebaiknya kain kafan yang telah tersusun dilipat terlebih dahulu untuk menjaga kebersihan atau kesucian kain kafan atau pertimbangan lainnya.

6. Jika jenazah telah selesai dimandikan dan dikeringkan badannya dengan dilap dengan kain yang bersih, jenazah dapat diletakkan di atas kain kafan yang telah dipersiapkan sebelumnya, dengan posisi badan ditelentangkan dan tangannya desedekapkan.

7. Letakkan kapas yang telah diberi wewangian seperti kapur barus pada anggota tubuh jenazah yang berlobang, yang meliputi mata, lobang hidung, telinga, mulut, dan duburnya. Selain itu kapas juga dapat diletakkan pada anggota sujudnya, yang meliputi jidad, hidung, kedua siku, telapak tangan, dan jari-jari telapak kaki, jika itu semua diinginkan atau memungkin.

8. Memakaikan baju kurung, sewek atau sarung, dan sorban atau kerudung.

9. Selanjutnya mayat dibungkus dengan kain kafan yang menutupi seluruh tubuhnya, dengan cara melipat lapisan pertama yang dimulai dari sisi kiri dilipat ke sisi kanan. Kemudian sisi kanan dilipat ke sisi kiri.Perlakuan melipat seperti itu juga dilakukan terhadap kain kafan kedua atau ketiga.

10. Mengikat kain kafan yang diujung kepala dan kali.

11. Setelah mengikat kain kafan yang di ujung kepala dan ujung kaki, dilanjutkan mengikat setentang dadanya, perutnya dan lututnya agar kain kafan tidak mudah terbuka saat di bawa ke pemakamannya.

Secara umum, Sulaiman Rasjid menjelaskan tentang kain kafan yang baik adalah kain kafan yang baik maksudnya dengan baik sifatnya, baik cara memakainya, dan terbuat dari bahan yang baik pula (Sulaiman Rasdjid: 1994).

\section{Tataran Ideal Pelaksanaan Pelatihan}

Idealnya, sebelum pelaksanaan pelatihan penyelenggaraan jenazahdilakukan terlebih dahulu wawancara, tes kognitif, apektif dan psikomotor dengan peserta pelatihan. Setelah itu semua dilakukan, tahap berikutnya dilanjutkan dengan pemberian materi pelatihan secara umum sebelum praktek memandikan dan mengafani jenazah dilaksanakan.Dan untuk memandikan jenazah, yang seharusnya dilaksanakan di tempat tertentu dengan alat-alatnya yang telah disiapkan sebelumnya.

Pada proses memandikan jenazah, pada pelatihannya peserta pelatihan diarahkan untuk menghaluskan kapur barus dan sabun terlebih dahulu sebelum jenazah dimandikan selain menyiapkan air bersih sebanyak kebutuhan.

Sebelum masuk pada proses memandikan jenazah, diawali dengan mengingatkan para peserta pelatihan, bahwa yang ada pada posisi tentang pinggang jenazah adalah anggota keluarga terdekat jenazah. Hal itu dilakukan untuk mempermuda sekaligus mempercepat proses memandikan jenazah dimana 
untuk membersihkan kemaluan/ qubul dan dubur jenazah adalah anggota keluarga terdekatnya.

Proses memandikan jenazah, dimulai dengan mengguyurkan air biasa ke tubuh jenazah. Cara mengguyurkan setiap air ke jenazah adalah air yang diguyurkan ke jenazah di tunggu dengan punggung tangan orang yang mengguyurkan air denga jarak air yang diguyurkan dekat dari anggota jenazah.Setelah air biasa diguyurkan, dilanjutkan mengguyurkan air sabun. Setelah itu dilanjutkan dengan membersihkan tubuh jenazah dengan menggosoknya secara perlahan atau menggosok jenazah dengan cara tidak sampai menyakitinya. Membersihkan atau menggosok jenazah dengan tangan yang telah dialas dengan alas tangan yang telah disiapkan sebelumnya. Dalam membersihkan tubuh jenazah, termasuk membersihkan rongga-rongga jenazah, seperti gigi, hidung, dan qubul, dubur jenazah dengan kain kecil yang digulung yang juga telah disiapkan sebelumnya. Setiap rongga yang dibersihkan, kain gulungan yang digunakan tentu saja berbeda dengan cara diganti oleh yang membersihkannya apalagi untuk membersihkan kemaluannya depan dan belakang (qubul dan dubur).

Setelah jenazah diperkirakan sudah bersih, dilanjutkan kegiatan dengan memandikan jenazah dengan air bersih dan mewudhukkan jenazah.Setelah jenazah dimandi bersihkan dan diwudhukkan, kegiatan dilanjutkan dengan memandi sembilankan jenazah. Pada proses memandi sembilankan jenazah ditempuh dengan cara: mengguyurkan air dari kepala sampai kaki sebelah kanan jenazah, mengguyurkan air dari kepala sampai kaki bagian tengah jenazah, dan dilanjutkan mengguyurkan air dari kepala sampai kaki sebelah liri jenazah, masing-masing berjumlah tiga kali. Inilah yang disebut dengan mandi sembilan.Setelah jenazah dimandi sembilankan, kegiatan dilanjutkan dengan mengguyur jenazah dengan air kapur barus yang telah disaring sebelumnya atau air bunga supaya jenazahnya harum atau untuk menghilangkan/ mengurangi bau yang ada di tubuh jenazah. Terkait pengguyuran air kapur barus atau bunga ke tubuh jenazah, para pserta pelatihan juga diingatkan untuk tidak mengguyurkannya pada jenazah yang sedang ihram atau jenazah yang mati syahid.Setelah itu semua selesai dilaksanakan, jenazah dibawa ke tempat yang telah dipersiapkan untuk mengelap sekujur tubuh jenazah dengan handuk/ kain yang bersih yang diperkirakan jika dilap tidak mudharat bagi jenazah.Setelah itu kegiatan pelatihan dilanjutkan dengan praktek menggunting kain kafan.

Ketika salah seorang peserta praktek (test) memandikan jenazah, peserta yang lainnya memperhatikan jalannya kegiatan.Karena pada paraktek memandikan jenazah peserta diingatkan untuk tidak mengguyurkan air ke jenazah seperti layaknya kita mengguyurkan ke badan kita waktu mandi (dengan jarak dan caranya suka-suka) membuat peserta pelatihan tertawa sambil memperhatikan jalannya kegiatan.

Dari kegiatan pelatihan memandikan jenazah yang telah dilakukan yang dilanjutkan dengan tes praktek memandikan jenazah yang ditampilkan oleh peserta, Tim Pengabdian menemukan data sebagai informasi terbaru bahwa masyarakat Balung yang menjadi peserta pelatihan dapat dikatakan telah mampu 
untuk memandikan jenazah. Penemuan data itu diperkuat lagi dengan adanya pengakuan peserta akan kemampuan mereka melalui tanya jawab yang dilakukan Tim Pengabdian tentang memandikan jenazah setelah pelatihan memandikan jenazah dilaksanakan untuk mengatahui kemampuan kognitif masyarakat desa Balung. Dengan kata lain dapat dikatakan bahwa, masyarakat desa Balung yang menjadi peserta pelatihan tidak hanya mampu memandikan jenazah secara kognitif saja tetapi juga mampu secara apektif dan psikomotor dengan adanya mereka mampu mempraktekkan memandikan jenazah sesuai arahan pada pelatihan yang telah dilaksanakan.

Kemudian untuk pelatihan mengafani jenazah, peserta pelatihan diingatkan kembali bahwa pengguntingan kain untuk jenazah biasanya dan itu harus dilakukan sebelum jenazah dimandikan. Terkait cara atau model yang ditampilkan dilakukan di hadapan peserta pelatihan, hanya karena untuk memudahan tahapan pelaksanaan pelatihan saja. Sebelum mengafani jenazah, peserta pelatihan diberikan pengetahuan tentang beberapa hal tentang mengafani jenazah, di antaranya termasuk praktek menggunting kain kafan.Setelah memberikan pengetahuan tentang mengafani jenazah disampaikan kepada para peserta, instruktur melanjutkan kegiatan pelatihannya dengan memberi contoh praktek memotong atau menggunting kain kafan.

Pada pemotongan kain kafan yang dicontohkan Tim Pengabdian di hadapan peserta pelatihan, Tim Pengabdian memberikan beberapa alternatif pilihan untuk lembaran kain kafan jenazah. Di antara berberapa alternatif pilihan kain kafan tersebut adalah :

1. Bagi mayat laki-laki yang lebih utama jumlah kain kafannya adalah 3 lembar/ 3 lapis dengan ukuran panjang dan lebar ketiga kain kafan sama. Selain itu, ada beberapa pendapat yang berkembang yang dipandang sempurna juga jika jenazah dikafani dengan 5 lapis kain kafan. Lima lapis lapis kain kafan tersebut, bisa terdiri dari 3 lapis dengan ukuran panjang dan lebar ketiga kain kafan sama untuk pembungkus seluruh tubuh, ditambah surban dan baju kurung, atau 2 lapis dengan ukuran panjang dan lebar kedua kain kafan sama untuk pembungkus seluruh tubuh jenazah berdasarkan ukuran panjang jenazah yang dilebihkan satu jengkal dari kepalanya dan satu jengkal dari telapak kakinya, ditambah surban, baju (baju yang dipersiapkan bisa berbentuk jubah dengan ukuran panjangnya dari bahu sampai tumit kaki jenazah dan bisa juga baju biasa dengan ukuran panjangnya dari bahu sampai pinggul jenazah) dan sarung, atau 3 lapis kain kafan dengan ukuran panjang dan lebar ketiga kain kafan sama, ditambah jubah dan sorban atau yang lainnya selama bilangan lapis kain kafannya ganjil.

2. Bagi jenazah perempuan yang kain kafannya 5 lapis, dapat dialokasikan untuk kain kafan dengan rinciannya 2 lapis kain kafan dengan ukuran panjang dan lebar kedua kain kafan tersebut sama (berdasarkan panjang kain kafan yang diukur dari kepala sampai kaki yang dilebihkan satu jengkal dari kepala dan kaki jenazah) untuk pembungkus seluruh tubuh jenazah, ditambah kerudung, baju kurung (baju yang dipersiapkan bisa berbentuk jubah dengan ukuran panjangnya dari bahu sampai tumit kaki jenazah dan bisa juga baju 
biasa dengan ukuran panjangnya dari bahu sampai pinggul jenazah) dan sewek/ kain sarung, atau persi yang lainnya sebagaimana yang telah disebutkan sebelumnya pada konsep teori.

Setelah selesai memberikan contoh cara menggunting kain kafan bagian luar sebanyak 3 lembar (2 lembar untuk kain kafan bagian luar dan satu/ 1 lembar untuk kain basahan/ mandi jenazah) yang diukur panjang jenazahnya terlebih dahulu dengan tali, dilanjutkan menggunting kain untuk baju jenazah dengan ukuran panjangnya dari bahu sampai pinggul jenazah yang diukur dengan tali sebelumnya. Setelah kain kafan seukuran untuk baju jenazah diambil, kain kafan untuk baju tersebut dilipat dua bagian lebarnya. Itu dilakukan untuk membuat leher baju jenazah dengan menggunting sedikit bagian tengah yang di depan dekat leher baju.

Setelah baju jenazah selesai digunting, tahap berikutnya menggunting kain kafan untuk jilbab bagi mayat perempuan/ sorban bagi mayat laki-laki. Pemotongan kain ini jugadilakukan dengan mengukur jenazah dengan tali terlebih dahulu dari kepala sampai dadanya. Setelah itu kain untuk jilbab atau sorban tersebut dilipat membentuk 3 persegi.

Setelah pemotongan kain kafan untuk jilbab selesai dipotong, dilanjutkan dengan pemotongan kain kafan untuk kain sarung. Pemotongan kain kafan untuk kain sarung juga dilakukan dengan mengukur jenazah terlebih dahulu sama dengan yang lainnya. Hanya saja bedanya, untuk kain sarung panjangnya adalah dari pinggang sampai tumit kaki jenazah.Setelah pemotongan semua kain kafan selesai dilaksanakan, tahap berikutnya dapat dilanjutkan dengan memotong sedikit saja lalu ditarik sampai putus setiap pinggir kain kafan yang dari fabrik untuk tali pengikat jenazah yang sudah dibungkus.Untuk pemotongan tali pengikat/ pinggir kain kafan dapat juga dilakukan sebelum pengambilan kain kafan pada umumnya dilakukan.

Setelah selesai pemotongan kain kafan sebagaimana yang disebutkan sebelumnya selesai dilaksanakan, tahap berikutnya dilanjutkan dengan pemotongan kain untuk alas tangan orang yang memandikan jenazah seukuran 1x1 jengkal. Setelah selesai memberikan contoh pemotongan kain kafan untuk sarung atau alas tangan orang yang akan memandikan jenazah, dilanjutkan dengan pemberian contoh pemotongan kain kafan untuk membersihkan rongga-rongga jenazah dengan ukuran kain kafan 1x1 jengkal yang digulung kecil.

Setelah selesai melakukan pemotongan terhadap beberapa kain kafan yang dibutuhkan, kegiatan selanjutnya adalah membentang tali pengikat untuk kain kafan jenazah dan menyusun kain kafan di atas tali. Pada penyusunan tali dan kain kafan jenazah, dilakukan dengan cara: Pertama, tali diletakan pada posisi: di atas kepala jenazah satu lembar dengan ukuran panjang secukupnya, setentang dadanya satu lembar, setentang perutnya satu lembar, setentang lututnya satu lembar, dan setelah tumitnya satu lembar sehingga berjumlah semuanya 5 lembar. Kedua, meletakkan dua lembar kain kafan pembungkus jenazah dan kapas di atasnya (jika ada kapas, diletakkan pada posisi kepala dan seluruh badan jenazah) ,Ketiga, meletakkan jilbab bagi jenazah perempuan atau sorban bagi jenazah lakilaki, Keempat, meletakkan kain sarungnya, Kelima melatakkan kain kafan untuk 
bajunya dengan memberi kapur barus halus yang telah disaring di setiap lembaran kain kafannya jika memungkinkan/ diinginkan.

Setelah instruktur selesai meberikan penjelasan tentang menggunting dan menyusun kain kafan yang diiringi dengan contoh prakteknya kain kafan telah disusun sesuai urutannya dilipat menjelang jenazah dimandikan.Kegiatan selanjutnya adalah peserta dites sambil diobservasi untuk mengetahui kamampuan kognitif, apektif dan psikomotornya. Untuk mengetahui kemampuan kognitif masyarakat desa Balung yang menjadi peserta pelatihan dengan cara mengajukan beberapa pertanyaan terkait tata cara menggunting dan menyusun kain kafan. Dari beberapa pertanyaan yang diajukan Tim Pengabdian mengamati bahwa, para peserta pelatihan dengan semangat menjawab pertanyaan yang diajukan dengan benar. Untuk mengetahui kemampuan apektif dan psikomotor para peserta pelatihan, para peserta pelatihan praktek lansung di hadapan Tim Pengabdian dan di depan peserta pelatihan lainnya. Dari tahapan-tahapan yang para peserta pelatihan praktekkan terkait menggunting dan menyusun kain kafan, Tim Pengabdian melihat bahwa mereka yang ikut pelatihan mampu menggunting dan menyusun kain kafan sesuai dengan yang telah dicontohkan.Setelah para peserta pelatihan diperkirakan telah mampu untuk menggunting dan menyusun kain kafan jenazah, kegiatan selanjutnya adalah memberikan pengetahuan terkait tata teknis membungkus jenazah sekaligus dengan contoh pelaksanaannya.Dan di saat instruktur memperagakan tahapan-tahap praktek membungkus jenazah, para peserta pelatihan diingatkan juga untuk tetap semangat memperhatikannya.

Setelah kegiatan pelatihan selesai dilaksanakan, idealnya dilakukan penilaian menuju evaluasi pelaksanaan pelatihan untuk mengetahuan kemampuan peserta pelatihan dan hal-hal lainnya yang ada hubungannya dengan refleksi social pelatihan terhadap peserta pelatihan.Dari kajian itu, dengan telah dilaksanakannya pelatihan penyeleenggaraan jenazah ini, tentunya tujuan yang diinginkan adalah mampunya mahasiswa PGMI dalam memandikan dan mengafani jenazah.Sesungguhnya itu semua sebagai bagian dari usaha menciptakan kedamaian dan integrasi sakinah (Fazlur Rahman: 1992) di kalangan umat Islam. Walaupun kita berada di zaman globalisasi informasi yang penuh dengan tantangan, sebagai umat Islam mudah-mudahan saja kita tetap memperluas cakrawala, yang mengantarkan semakin kreatifnya (Nurcholish Madjid: 2009) umat, termasuk dalam hal memandikan dan mengafani jenazah, sebagai suatu model (Nuscholish Madjid, dkk. : 1996) yang tetap relevan di era ini. Al-Quran menyeru umat manusia supaya menyimak sejarah agar bisa menarik pelajaran, memperbaiki prilaku dan menyelaraskannya dengan ketentuan yang telah digariskan (M. Umer Chapra: 2010) dalam ajaran agama, sebagai bagian dari jantung keyakinan kita.Dan jantung dari keyakinan Islam adalah kepercayaan kepada ke-Esaan Allah, baik secara lansung atau tidak lansung termasuk di dalamnya yang berkaitan dengan persoalan kemanusiaan sebagai bentuk refleksi sosial umat yang sehat mentalnya.Pengalaman komunitas Islam merupakan bagian pokok dari misi Islam dan usaha menciptakam masyarakat yang Rabbani (John Obert: 1997).Betapa eratnya hubungan antara agama dengan kesehatan mental (Zakiah Daradjat: 1993) umat menuju refleksi sosial.Sungguh Al-Quran 
berada di atas akal dan kemampuan manusia sampai akhir zaman (Munzir Hitami: 2008), untuk direalisasikan umat di sepanjang kehidupannya. Semoga kajian ini memberi manfaat, dan keberkahan untuk kita semua.Amiin.

\section{E. Penutup}

Setelah dilakukannya pelatihan penyelenggaraan jenazah terkait memandikan dan mengafani jenazah apalagi diiringi dengan memberikan pemahaman kepada pesertaakan pentingnya kemampuan itu dalam ajaran syariat Islam. Dengan kegiatan pelatihan ini diharapkan dapat membangkitkan motivasi peserta untuk mampu dalam penyelenggaraan jenazah, yang terefleksi dalam kehidupan sosialnya,baik secara kognitif, apektif maupun psikomotornya.

\section{REFERENSI}

Abuddin Nata, Sosiologi Pendidikan Islam, (Jakarta: Rajagrafindo Persada, 2014).

Alaiddin Koto, Sebelum Semua Menjadi Terlambat, (Yogyakarta: Pustaka Pelajar, 2010).

Fazlur Rachman, Islam, Terjemah., (Jakarta: Bumi Aksara, 1992).

Ibn Rusyd, Bidaayatul Mujtahid, Terjemah. Imam Ghazali Said, Jilid I, (Jakarta: Pustaka Amani, 1996).

John Obert Voll, Politik Islam: Kelangsungan dan Perubahan di Dunia Modern, (Yogyakarta: Titian Ilahi Press, 1997).

M. Umer Chapra, Peradaban Muslim Penyebab Keruntuban dan Perlunya Reformasi, Terjemh., (Jakarta: Amzah, 2010),

Ma'mur Daud -penterjemah, Shaheh Muslim, Terjemh. (Jakarta: Widjaya, Jilid III, 1982).

Muhaimin, Paradigma Pendidikan Islam, (Bandung: Remaja Rosdakarya, 2001),

Muhammad Jawad Mughniyah, Fiqih Lima Mą̧ab, (Jakarta: Lentera Basritama, Cet. Ke-2, 1996).

Munzir Hitami, Menelisike Keberagamaan Kita: Esai-esai tentang Moralitas, Pendidikan dan Keragaman Pemahaman Beragama, (Pekanbaru: Suska Press, 2008),

Nurcholish Madjid, Kaki Langit Peradaban Islam, (Jakarta: Dian Rakyat, 2009).

Sulaiman Rasjid, Fighi Islam, ( Bandung: Sinar Baru Algesindo, Cet. 27, 1994).

Yayasan Penyelenggara/ Penafsir Al-Quran (Revisi Terjemah oleh Lajnah Pentashih

Mushaf Al-Quran Kemenag RI), Al-Quran dan Terjemahan Mushaf Al-Hilali, (Jakarta: CV. Alfatih Berkah Cipta, 2012).

Yusuf Al-Qaradhawi, Distorsi Sejarah Islam, (Jakarta: Pustaka Al-Kautsar, 2013). 